\title{
EXPERIENCED ENGLISH TEACHERS' PERSPECTIVES ON THE FULFILLMENT OF ONE-PAGE LESSON PLAN PRINCIPLES AT SMAN 1 SINGARAJA
}

\author{
Putu Agus Januarta ${ }^{1}$, I.G.A. Lokita Purnamika Utami ${ }^{2}$, \& Ida Ayu Made Istri Utami ${ }^{3}$ \\ ${ }^{1}$ Universitas Pendidikan Ganesha \\ ${ }^{2}$ Universitas Pendidikan Ganesha \\ ${ }^{3}$ Universitas Pendidikan Ganesha \\ januartaagus71@gmail.com, lokitapurnamika@undiksha.ac.id, istriutami@undiksha.ac.id
}

\begin{abstract}
This research aims at analyzing the experienced English teachers' perspectives on the fulfillment of one-page lesson plan principles at SMAN 1 Singaraja. The research design used a case study qualitative approach. The research subjects were 2 experienced English teachers. The data collection procedure used in this study was an in-depth interview. The instruments of data collection procedure used was interview guides. The results revealed that the experienced English teachers' perspectives were positive as the teachers believed that the one-page lesson plan was more efficient, effective, and more student-oriented so that the teachers could make simple lesson plan easily. These results showed that the principles of developing the one-page lesson plan have been implemented well based on the Circular Letter Number 14 of 2019 concerning Simplification of the Lesson Plan. Besides, the policy on the simplification of lesson plan needs to be maintained as it gains positive responses from the experienced English teachers.
\end{abstract}

Keywords: perspectives, one-page lesson plan princples, experienced teachers

\begin{abstract}
Abstrak: Penelitian ini bertujuan untuk menganalisis perspektif guru bahasa Inggris berpengalaman tentang pemenuhan prinsip RPP satu halaman di SMAN 1 Singaraja. Desain penelitian menggunakan pendekatan kualitatif studi kasus. Subjek penelitian adalah 2 orang guru bahasa Inggris yang berpengalaman. Prosedur pengumpulan data yang digunakan adalah wawancara mendalam. Instrumen prosedur pengumpulan data yang digunakan adalah pedoman wawancara. Hasil penelitian mengungkapkan bahwa perspektif guru bahasa Inggris yang berpengalaman adalah positif karena guru tersebut meyakini bahwa RPP satu halaman lebih efisien, efektif, dan lebih berorientasi pada siswa sehingga guru tersebut dapat membuat RPP yang sederhana dengan mudah. Hasil ini menunjukkan bahwa prinsip-prinsip penyusunan RPP satu halaman telah dilaksanakan dengan baik sesuai dengan Surat Edaran Nomor 14 Tahun 2019 tentang Penyederhanaan Rencana Pelaksanaan Pembelajaran (RPP). Selain itu, kebijakan penyederhanaan RPP ini perlu dipertahankan karena mendapat respon positif dari para guru bahasa Inggris yang berpengalaman.
\end{abstract}

Kata Kunci: perspektif, prinsip RPP satu halaman, guru berpengalaman

\section{INTRODUCTION}

A lesson plan is one of the important aspects that a teacher needs to plan properly in order to make learning process can run effectively, efficiently, directed. According to Haynes (2010), designing the lesson plan before the teachers carrying out the teaching and learning process can help the teachers to design what their teaching and learning process is like in the classroom. The teaching and learning process will also be more effective if the teachers design the lesson plan properly (Boikhutso, 2010). In other words, lesson plan is one of the important requirements for teachers to design learning activities as their preparation before the teaching and learning process begins. Callahn \& Clark 
(1988) states that teaching without written preparation will create such an ineffective learning in the classroom because the teacher does not think in detail about what to do and how to do it. Thus, realizing the importance of lesson plan in learning can affect the quality of education in Indonesia.

Designing a lesson plan must be related to the education system that is implemented, including the curriculum. The curriculum used in Indonesia currently is curriculum 2013. The curriculum 2013 emphasizes on the teaching and learning process at classroom which should be interactive, pleasant, challenging, inspiring and able to motivate the learners to be active participants and give them an opportunity to develop their knowledge, creativity, and independence based on their interest and ability. However, the implementation of the curriculum 2013 may affect the change in designing the lesson plan because the changes of required elements to be included in the lesson plan. As finding of research by Ilma \& Pratama (2015) reveals that educators' perspective regarding the curriculum 2013 is too early to be implemented. These perspectives can also be related to the revision of lesson plans that have been done previously during the implementation of this curriculum.

The previous lesson plan of the curriculum 2013 is considered as complex lesson plan. It is due to this lesson plan contains 13 components that should be fulfilled by teachers. From those components cause them more focused in designing the lesson plan in detailed than evaluating the learning process itself. In other words, these components become the challenges and difficulties faced by the teachers to design lesson plans well. According to Gani et al, (2017) the lesson plan of curriculum 2013 is currently more difficult to design than the KTSP curriculum in term of developing the authentic assessment rubric and formulating the indicator. In addition, it should also create and state basic competence $(K D)$ in the lesson plan. Besides, the teachers also feel less effective and efficient in designing the lesson plan because the format of the lesson plan is so complex and detailed. It can be said that designing the previous lesson plan spent a lot of time for the teacher, which should be used to prepare and evaluate the learning process itself, as well as some teachers also argue that the previous lesson plan less directed student-oriented learning. Therefore, the teachers are still difficult to design the lesson plans well.

Regarding the challenges that the teachers faced during designing the previous lesson plan of the curriculum 2013, the Education Minister released a new policy about the new format of lesson plan which is written in Circular Letter Number 14 of 2019 concerning Simplification of the Lesson Plan. The purpose of simplifiying the lesson plan is to lighten the administrative burden on teachers and give teachers the freedom to be creative and innovate in the learning process (Iskandar, 2020). In the circular letter, it is explained that from the 13 components of the lesson plan which had been regulated in the Decree of the Minister of Education and Culture Number 22 of 2016 concerning Basic and Secondary Education Process Standards was revised into a one-page lesson plan which focused on the main components, namely learning objectives, learning steps/activities, and learning assessment, meanwhile the other components are complementary. Besides, the writing of the lesson plan is carried out on the principles of efficiency, effectiveness, and studentorientation. From the new policy, the Education Minister believes that using the one-page lesson plan, the teachers can create lesson plan well according to the principles of 
efficiency, effectiveness, and student-oriented quality, as well as they have also more time to prepare and evaluate the learning process itself.

The teachers' perspectives must also be considered as the principles of developing the one-page lesson plan. The lesson plan principles are believed to be able to contribute to teachers in making good and simple lesson plans (Iskandar, 2020). For that, it is important to identify teachers' voice on their fulfillment to principles of developing the one-page lesson plan. The perspectives of the teachers can be taken from experienced teachers especially for the English teachers. The perspectives of experienced English teachers have a significant role in the use of the lesson plan during their learning process because they are the one will implement the lesson plan. There are several experienced teachers in Indonesia have made and used the one-page lesson plans in their teaching and learning process in the classroom. Besides, there are factors for teachers who use the onepage lesson plan, namely the simplicity of the lesson plan which can lighten the administrative burden, and then it can be used as an improvement of the education quality.

SMAN 1 Singaraja is one of the schools in Bali that has implemented the one-page lesson plan in every subject especially English learning. This school is one of the most excellent schools which has many teachers who are competent in their respective fields especially English teachers. In carrying out the learning process, the teachers used the one-page lesson plan which is adjusted to Circular Letter Number 14 of 2019 concerning the Simplification of the Lesson Plan as their guidance. Furthermore, this school has two experienced English teachers. In fact, they have made the one-page lesson plan. Even though they have made the one-page lesson plan based on the circular letter, they may have their own perspectives regarding the lesson plan whether it is efficient, effective and students-oriented or not. Thus, it is important to identify and explore the perspective of experienced English teachers regarding the one-page lesson plan principles.

However, a little attention has been given to the perspectives of experienced English teachers regarding the fulfillment of one-page lesson plan principles at SMAN 1 Singaraja. Therefore, the research on the perspectives of experienced English teachers regarding the fulfillment of one-page lesson plan principles at SMAN 1 Singaraja needs to be done. This study aims to analyze the perspectives of experienced English teachers on the fulfillment of one-page lesson plan principles at SMAN 1 Singaraja. By learning the teachers' perspectives, it can provide a clear picture of how their attitudes, beliefs or point of view/opinions regarding the fulfillment of one-page lesson plan principles, and whether their perspectives are similar or different or even positive or negative regarding the issue.

\section{METHODS}

This research used a case study qualitative approach. The case study was chosen to analyze and explore the perspectives of English teachers who have implemented a onepage lesson plan at SMAN 1 Singaraja. The subjects of this study were 2 experienced English teachers at SMAN 1 Singaraja. The technique used to select the teachers based on the functional positions with group IVa to IVe. Based on Government Regulation Number 35 of 2010 concerning Technical Guidelines for the Implementation of Teacher Functional Positions and Credit Figures, the functional positions with group IVa, IVb, and IVc categorized as middle teacher, and then the functional positions with group IVd 
and IVe categorized as main teacher. Teachers who have functional positions with group IVa to IVe can be considered as the teachers who have a lot of experience in teaching. Thus, the functional positions with group IVa to IVe can be used as experienced teachers. Data collection procedures used in this study was an in-depth interview. The instrument used in collecting the data was interview guides. In developing the interview guide, questions were developed to reflect the one-page lesson principles, namely efficiency, effectiveness, and students-oriented quality.

Futhermore, data analysis method used in this study was an interactive analysis model proposed by Miles and Huberman (1994). This model has four stages such as data collection, data reduction, data display, and drawing conclusions/verification data. In collecting data, the researcher obtained the data from the results of interview. In displaying data, the researcher returned to the stage of data collection to find out all necessary data is collected. In drawing conclusion stage, the researcher returned to the data reduction when unnecessary data is collected. In addition, when the researcher drew a conclusion, the researcher returned to data collection because the results of data analysis are not enough to answer the research questions. Then, the verification was done by relating the findings with the literature review.

\section{RESULTS AND DISCUSSION}

In this phase, the perspectives of experienced English teachers on the fulfillment of one-page lesson plan principles is described. The data was gathered from the interview section with the respondents. After the data has been sorted through data coding and data reduction, the answers were grouped into some categories to be analyzed and elaborated more efficiently. These teachers' perspectives were organized following the name of the principles of one-page lesson plan, the perspectives regarding their lesson plan's efficiency, effectiveness, and students-oriented quality.

First is the perspectives of experienced English teachers regarding the efficient principle of one-page lesson plan. This term is important because it can support the teachers in making the one-page lesson plan well. In fact, both experienced English teachers provided positive point of view which they viewed that the creation and development of the one-page lesson plan was more efficient than the previous lesson plan. The transcription of the interview is presented as excerpt 1 and excerpt 2 below:

\section{Excerpt 1}

ET1 : (I spent about 1 day for making a one-page lesson plan. To make lesson plan with 13 component formats, I spent a longer which was about 3 days).

ET2 : (If the one-page lesson plan, I spend about 2 hours. If the previous lesson plan, it could be 3 days. Because it includes 13 components and is made in detail, while the one-page lesson plan only includes learning objectives, learning steps, and assessment of learning outcomes).

\section{Excerpt 2}

ET1 : (Yes, it has saved time, because this lesson plan format is simpler by including only the most important components compared to the previous lesson plan where the one-page lesson plan contains only 3 
core components, namely learning objectives, learning steps and learning assessments. Meanwhile, other components are used as a complement only).

(Yes, it is enough to lighten my effort, because with a simpler lesson plan format like this one-page lesson plan, automatically the time needed to make it is shorter and also saves energy).

ET2: (It saves time, because this lesson plan is shorter and simpler which only thinks about and prioritizes only important things such as learning objectives / what goals students will achieve, and then how to take effective steps to achieve these goals. Then, we also focus on assessing learning outcomes whether the goals we previously set have been achieved or not).

(It is very lightening, because this lesson plan includes a simpler teacher administration and also saves time, effort and cost in its preparation).

Notes $\quad$ Translated from Indonesian
ET1 $:$ Experienced Teacher 1
ET2 $:$ Experienced Teacher 2

From the excerpt 1 and excerpt 2, it was found that the teachers did not need a lot of time in designing and making the one-page lesson plan in which ET1 spent about 1 day to make the lesson plan and ET2 only spent about 2 hours to make the lesson plan. Meanwhile, compared to the previous lesson plan which used 13 component formats, the teachers spent 3 days longer to make it. Besides, they also felt that the one-page lesson plan format was more simple and shorter because this lesson plan format only included main components or important points which it could save time and lighten their effort, both energy and costs in the making process. This showed that this one-page lesson plan was more efficient to design compared to the previous lesson plan. Thus, this is in line with the efficient principles which the writing of the lesson plan is done correctly and does not take a lot of time and effort (Iskandar, 2020).

Second is the perspectives of experienced English teachers regarding effective principle of one-page lesson plan. This term is one of the important parts which can support the teachers in creating the one-page lesson plan with the aim of achieving learning objectives effectively. In fact, both experienced English provided positive point of view which they viewed that the one-page lesson plan was more effective than the previous lesson plan. The transcription of the interview is presented as excerpt 3 below.

\section{Excerpt 3}

ET1 : (Yes, it is better to use the one-page lesson plan, because the implementation is much more flexible and effective so that the goals set are more measurable and well achieved, and the use of this lesson plan can make teachers focus more on preparing to achieve the goals in their learning).

(...The one-page lesson plan can give a quite significant impact on the achievement of learning objectives, because every teacher is required to make lesson plans before teaching. This aims to make learning more tearful and measurable so that the goals can be 
achieved. So, making this lesson plan can give a significant impact on the achievement of learning objectives...).

ET2: (Yes, for me, the one-page lesson plan is better, because it saves energy, costs, time, and the implementation is much more flexible and effective so that the goals set are more focused and maximally achieved).

(...This lesson plan gives a significant impact on the achievement of learning objectives because in this lesson plan, especially the learning steps it is implied what is prepared by the teacher, what is done by the teacher, and what students do in the classroom as well as the learning steps. activities that adjust the goals set).

Notes : Translated from Indonesian

ET1 : Experienced Teacher 1

ET2 : Experienced Teacher 2

From the excerpt 3 and excerpt 4, it was found that they viewed the one-page lesson plan to be more effective for achieving learning objectives because in terms of implementation of what is written in the lesson plan, it is much more flexible and effective which could make them more focused on preparing both energy and time to achieve the goals measuredly, maximally and effectively. In addition, the use of the one-page lesson plan could give a quite significant impact towards the achievement of learning objectives. This is also in line with the effective principles which the writing of lesson plans is done to achieve learning objectives (Iskandar, 2020).

Third is the perspectives of experienced English teachers regarding students-oriented principle of one-page lesson plan. This term is one of the important parts which can support the teachers in making the one-page lesson plan considering students' readiness, interests and needs in class. In fact, both experienced English teachers provided also positive point of view which they viewed that when making the one-page lesson plan, it considered students' readiness, interests, and needs. The transcription of the interview is presented as excerpt 4 , excerpt 5 , and excerpt 6 below.

\section{Excerpt 4}

ET1 : (Students' background knowledge, availability of learning support materials that can make learning challenging but interesting and beneficial for students).

ET2 : (I consider the readiness of students' background knowledge about the material being taught, the readiness of students to learn individually, in pairs, or in groups...).

\section{Excerpt 5}

ET1 : (Based on previous teaching experiences, we can find out how the characteristics of our students, especially the material we are conveying to students. Characteristics of students can be like students are more interested with material related to the latest information).

ET2 : (For me, I am more concerned with and provide materials or assignments to the students in accordance with the context of their 
environment or their daily lives. So, what they do in their works already has their environment, be it the family environment, the community environment, and so on. From this context, students will be interested in learning).

\section{Excerpt 6}

ET1 : (Based on the competencies and syllabus that have been made, we will know the direction of our learning objectives and the needs of students in the classroom. At the beginning of the semester too, the students and teachers will hold a meeting to agree on the material to be studied in that one semester).

ET2 : (...the needs of students in terms of their lives individually and socially. Individual lives can be in the form of their intellectuals and skills while social life can be in the form of group learning, collaboration and so on, because our children (students) cannot learn only individually but group learning is important. From group learning, they can certainly learn to solve problems together. In addition, I also determine that (students' needs) based on the curriculum that has been prepared by the Ministry of Education and Culture).

Notes : Translated from Indonesian ET1 : Experienced Teacher 1 ET2 : Experienced Teacher 2

From the excerpt 4, excerpt 5 and excerpt 6 , it was found that the teachers always considered the students' readiness, interests and needs when making and designing the one-page lesson plan. This can give a positive influence on the success of the learning process. For the students' readiness, the teachers were more concerned with the students' background knowledge. For the students' interests, the teachers were more concerned with the interesting material related to current information/their environment. Further, the teachers used the curriculum reference to determine the students' needs. This is also in line with the students-oriented principles which the writing of lesson plans that is done by considering the readiness, interests, and learning needs of students in the class (Iskandar, 2020). In addition, the current finding is also compared to the previous lesson plan in which when designing a lesson plan, the teachers applied less the student-oriented principles. Hence, the previous lesson plan allowed the teachers to be less studentsoriented such as less consider the students' readiness, interest, and needs.

Based on the results, both experienced English teachers had positive perspectives which they viewed that the one-page lesson plan format was more efficient, effective, and more student-oriented compared to the previous lesson plan. The teachers also perceived that the one-page lesson plan is better than the previous one. It is due to the teachers only required important components, namely three main components such as learning objectives, learning activities, and learning assessment. This showed that the one-page lesson plan was not too complicated. When developing and making the one-page lesson plan, the teachers always considered the students' readiness, interests and needs which can give a positive influence on the success of the learning process.

Compared with previous research from Saputri (2017) which studied of English teachers' difficulties in designing lesson plan based on 2013 curriculum. She found that the teachers had some difficulties in designing the previous lesson plan. The difficulties 
such as developing and stating indicators are related to the basic competence, developing the learning material, and selecting teaching method, learning materials, and technique of authentic assessment. Thus, it can be assumed that the previous lesson plan can make the teachers feel difficult in designing a good lesson plan. These difficulties can cause the making of previous lesson plan need a long time and also spend a lot of energy.

In addition, the result of research by Palobo et al., (2018) which studied the difficulties faced by junior high school teachers in developing lesson plans based on the curriculum 2013. He found that the teachers had difficulties in developing the previous lesson plan. The difficulties that can be described, namely (1) developing indicators of competency achievement, (2) developing schemes to achieve basic competencies, (3) developing apperception activities, (4) development of core activities, (5) designing activities to draw conclusions, and (6) formulating assessments. Thus, the finding can also be assumed that the previous lesson plan can make the teachers feel difficult in designing a good lesson plan. These difficulties can also be the cause for the teacher which in the process of making of previous lesson plan need a long time and also spend a lot of energy.

Viewed from the results of research from Saputri (2017) and Palobo et al., (2018), the use of the one-page lesson plan format is more efficient, effective and easier to design because the planning of the lesson plan is more flexible that only includes important components such as learning objectives, learning steps/activity, and learning assessment. In addition, using the one-page lesson plan format can save time and effort in the making process. When making the one-page lesson plan, it is not necessary to state basic competences and indicator, learning materials, learning methods, and how technique of authentic assessment or formulating assessment in detail but this lesson plan is written briefly on one page with a more flexible plan which adjusts with the students' readiness, interests and needs (student-oriented). In addition, the experienced English teachers also perceive that the use of one-page lesson plan could give quite a significant impact on the achievement of learning objectives and the use of this lesson plan was more effective in achieving learning objectives. From their perspectives, it can be assumed that the principle of developing the one-page lesson plan has been implemented well in accordance with the Circular Letter Number 14 of 2019 concerning Simplification of the Lesson Plan. Thus, by following the principles of lesson plan, the teachers could make simple lesson plan easily.

\section{CONCLUSIONS}

In conclusion, the perspectives of experienced English teachers on the fulfillment of one-page lesson plan principles were positive in terms of the one-page lesson plan was more efficient, effective, and more students-oriented. It is due to the lesson plan format only included important components and was not too complicated. In term of effectiveness, the use of one-page lesson plan could give contribute on the achievement of the learning objective. In addition, the English teachers always considered the students' readiness, interests, and needs when making and designing the one-page lesson plan. Related to students' readiness, the teachers were more concerned with students' background knowledge. The teachers were also more concerned with interesting material related to current information/their environment as considering the students' readiness. Further, the teachers used the curriculum reference to determine the students' needs. From 
their perspectives, it showed that the principle of developing the one-page lesson plan has been implemented well. By using these principles, the teachers could make simple lesson plan easily.

Besides, the result of this study implies that the experienced English teachers have understood and are able to develop one page lesson plan as stipulated in the Circular Letter Number 14 of 2019 concerning the Simplification of the Lesson Plan. In addition, the policy on the simplification of lesson plan needs to be maintained as it gains positive responds from the experienced English teachers.

With the result of this study, hopefully the other teachers can use the one-page lesson plan format by following the principles of developing lesson plan, namely efficient, effective, and students-oriented because this can make other teachers feel efficient and effective in the making process, and this lesson plan can be more studentsoriented. Besides, the next researcher is expected to explore deeper information about the perspectives English teachers on considering students' needs in making one-page lesson plan. It is because the English teachers at SMAN 1 Singaraja still consider the students' needs by using the curriculum reference only.

\section{REFFERENCES}

Boikhutso, K. (2010). The theory into practice dilemma: Lesson planning challenges facing botswana student-teachers. Improving Schools, 13(3), 205-220.

Callahan, Joseph F. and Leonard H. Clark. (1988). Teaching in the Middle and Secondary Schools: Planning for competence. New York: Macmillan Publishing Co.

Gani, S. A., Zulfikar, T., \& Sulisdawati, T. (2017). Perceptions of English Teachers About Lesson Plans for the KTSP and the 2013 Curriculum. English Education Journal (EEJ), 8(4), 503-517.

Haynes, A. (2010). The Complete Guide to Lesson Planning and Preparation. Continuum International Publishing Group.

Ilma, Z., \& Pratama, R. K. (2015). Transformation in Indonesian Language Curriculum: Pros and Cons between KTSP 2006 and Curriculum 2013 in Indonesia. 2013-2016.

Iskandar, H. (2020). Buku Saku: Tanya Jawab Rencana Pelaksanaan Pembelajaran (RPP). Jakarta: Kementerian Pendidikan dan Kebudayaan.

Miles, M. B. \& Huberman, A. M. (1994). An Expanded Sourcebook: Qualitative Data Analysis (Second Edition). London: Sage Publications.

Palobo, M., Sianturi, M., Marlissa, I., Purwanty, R., Dadi, O., \& Nur, A. S. (2018). Analysis of Teachers' Difficulties on Developing Curriculum 2013 Lesson Plans. Advances in Social Sciences, Education and Humanities Research, 226(ICSS), 1319-1324.

Peraturan Menteri Pendidikan dan Kebudayaan Nomor 22 Tahun 2016 tentang Standar Proses Pendidikan Dasar dan Menengah.

Saputri, M. (2017). “English Teachers' Difficulties in Designing Lesson Plan Based On 2013 Curriculum (A Descriptive Study in SMP Al-Islam 1 Surakarta)”. [Thesis]. English Education Department, Islamic Education and Teacher Training Faculty.

Surat Edaran Nomor 14 Tahun 2019 tentang Penyederhaan Rencana Pelaksanaan Pembelajaran (RPP). 